\title{
Speciation and mineral hosts of germanium in mine wastes: implications for recovery
}

\author{
SARAH JANE O. WHITE ${ }^{1 *}$, NADINE M. PIATAK ${ }^{1}$, RYAN J. \\ MCALEER $^{1}$, SARAH M. HAYES ${ }^{1}$, ROBERT R. SEAL, II ${ }^{1}$, \\ LAUREL A. SCHAIDER ${ }^{2,3}$, JAMES P. SHINE ${ }^{3}$
}

1US Geological Survey, Reston, VA ("sjowhite@usgs.gov); ${ }^{1}$ Silent Spring Institute, Newton, MA; ${ }^{3}$ Harvard T.H. Chan School of Public Health, Boston, MA

Germanium (Ge) is an element critical to current energy, defense, and communication technologies. Ge is produced from both coal fly ash and as a byproduct of zinc ( $\mathrm{Zn})$ mining; Ge has been discarded as waste produced by primary $\mathrm{Zn}$ mining for centuries. To understand the biogeochemical cycling of Ge related to mining and the conditions influencing its recoverability from mine wastes, we characterized mine wastes (chat) at the Tar Creek Superfund Site in Oklahoma, USA, where historical mining of sphalerite $(\mathrm{ZnS})$ and galena $(\mathrm{PbS})$ has left wastes elevated in lead $(\mathrm{Pb}), \mathrm{Zn}$, and cadmium $(\mathrm{Cd})$. Ge is elevated in chat compared to the average crustal concentration of 1.4 ppm. Small chat particles $(<37 \mu \mathrm{m})$ contain higher concentrations of $\mathrm{Ge}(9-17 \mathrm{ppm})$ than large particles $(>0.5$ $\mathrm{mm}$ ) (2-4 ppm), a similar pattern to $\mathrm{Pb}, \mathrm{Zn}$, and $\mathrm{Cd}$ distributions. The minerals that host Ge are critical determinants of its mobility, bioaccessibility, and potential for recovery from chat. Characterization using x-ray diffraction, electron microprobe analysis, mineral liberation analysis, synchrotron-based x-ray fluorescence mapping, and $\mathrm{x}$-ray absorption spectroscopy suggests that Ge is present in sphalerite $(<90-750 \mathrm{ppm})$ as expected. However, in some waste piles, hemimorphite $\left(\mathrm{Zn}_{4}\left(\mathrm{Si}_{2} \mathrm{O}_{7}\right)(\mathrm{OH})_{2} \cdot \mathrm{H}_{2} \mathrm{O}\right)$, which is primarily a weathering product, is the predominate host of Ge (up to $2200 \mathrm{ppm}$ ). Our findings demonstrate that weathering can alter the solid-phase speciation of critical elements in mine wastes, and highlight the importance of understanding this speciation in order to effectively target Ge for recovery. 